TITLE:

\title{
Status Update on the "OK" (Orphaned Kigoma) Chimps
}

$\operatorname{AUTHOR}(\mathrm{S})$ :

\section{CITATION:}

Status Update on the "OK" (Orphaned Kigoma) Chimps. Pan Africa News 1995, 2(2): 6-7

ISSUE DATE:

1995-10

URL:

http://hdl.handle.net/2433/143327

RIGHT:

Copyright (C) Pan Africa News. 


\section{Letter from Kigoma, 29 August 1995}

Rafiki, Dosi, Kipara and Zorro, the Kigoma Orphan Chimps, are very shortly to become the Kitwe Point Sanctuary Chimps. In September they will be moved from a cage behind the Aqua Lodge Hotel in Kigoma that has been their home since March, 1994, to the sanctuary.

Kitwe Point is a beautiful, wooded peninsula, three miles to the south of Kigoma on the shores of Lake Tanganyika. It covers an area of approximately fourteen acres. An adjoining 282 acres of land have also been given to the Jane Goodall Institute by the Tanzanian government. This whole area is the last protected land within Kigoma township and we feel very fortunate and priveleged to have the opportunity to contribute to its guardianship.

Sadly, of the original six chimps confiscated by the authorities in Kigoma last year, only four chimps remain because we lost the two females. One died very soon after confiscation and Karanga, our oldest chimp, died only recently of an illness. But the four young males ranging in age from two to approximately four years old are thriving. They receive devoted care and attention from Abdallah and Haruna, the permanent chimp caretakers who in the past were ably supported by a shift-system of Gombe workers. Volunteers from Britain, the United States and New Zealand have also played a magnificent part in caring for the chimps and working towards getting us to Kitwe Point. Soon there will be trees and grass and space for all - an exciting prospect!

Sally-Ann McOwan/ Kitwe Point Sanctuary/JGI-Kigoma 